
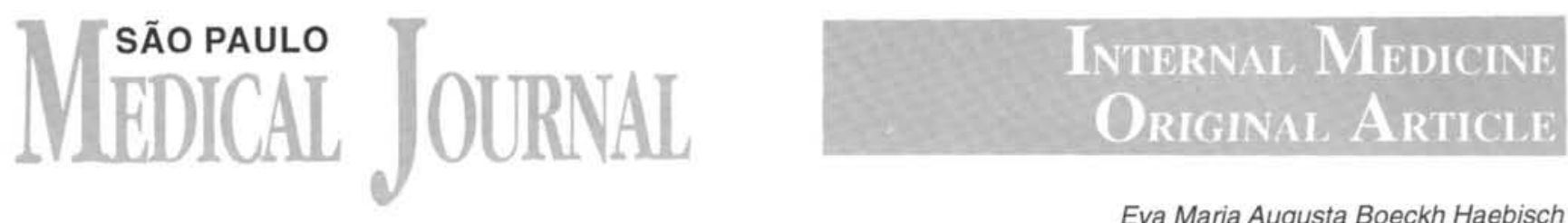

Eva Maria Augusta Boeckh Haebisch

\title{
Transdermal glyceryl trinitrate (nitroglycerin) in healthy persons: acute effects on skin temperature and hemodynamic orthostatic response
}

\author{
Pharmacology Department of the Instituto de Ciências Biomédicas \\ of the Universidade de São Paulo, Brazil
}

In order to find an explanation for individual reactions to transdermal glyceryl trinitrate (GTN) we studied the skin temperature and hemodynamic reactions in 63 healthy persons. The data were obtained before and after the application of GTN and Glycerin (GL) placebo patches, during one hour. The skin temperature was measured on both forearms, the local (left sided) and systemic (right sided) reaction on GTN was related to the skin fold and the calculated body fat content. The bilateral rise of skin temperature and its duration was higher and longer in obese than in lean persons mainly in obese women. The UV induced thermo and the later photothermoreaction (Erythema) was reduced on the left forearm after the application of GTN and GL patches. The observed hemodynamic GTN effect confirmed known postural reactions, such as decreased arterial pressure $(\Delta \mathrm{mAP}=-2.9 \%)$, increased heart rate $(\Delta \mathrm{HR}=$ $+7,4 \%)$ and $Q T c$ prolongation $(\Delta \mathrm{QTC}=+4,9 \%)$ in upright position. An adverse drug effect with increased mean blood pressure $(\Delta \mathrm{mAP}$ $=+12 \%)$ and increased heart rate $(\Delta \mathrm{HR}=+10.4 \%)$ mainly in supine position was observed in $11 \%$ of the participants, but only in men. Such a reaction was already described by Murell, 1879. Individual GTN effects were analyzed and related to habits and family history. In male smokers and in persons with hypertensive and diabetic close relatives, the hypotensive GTN effect was accentuated in supine position. In the upright position the group with hypertensives in the family presented a moderate hypotensive reaction without secondary tachycardia and the smokers presented only a slightly increased heart rate. Our observations suggest that individual reactions to transdermal glyceryl trinitrate (GTN) with its active component nitric oxide (NO) depends on physiological conditions, related to endogenous vasoactive substances, mainly the interaction with EDRF (the endogenous NO) and the activity of the Renin-Angiotensin System.

UNITERMS: Transdermal Glyceryl Trinitrate (GTN). Skin temperature. Orthostatic reaction. Healthy persons.

$\mathrm{W}$ illiam Murell in 1879 observed that "nitroglycerine" given to friends, and other persons and also taken by himself in "six or seven minutes after an oral dose increased the pulse pressure, heart rate (HR) and the systolic arterial pressure (sAP) and the dicrotic notch became more prominent" (1). We believe that glyceryl trinitrate (GTN) named at that time as nitroglycerin, was tested in healthy men. This

\section{Address for correspondence:}

Eva Maria Augusta Boeckh Haebisch

Rua Daniel Rossi, 164

São Paulo / SP - Brasil - CEP 02019-010 observation contrasts with the generally accepted concept that GTN in normal persons does not alter blood pressure and heart rate in supine position, but may provoke a postural hypotension with a secondary "reflex" tachycardia (2). With constant, low or high plasma nitrate levels, individual reactions are known: from abolished (3), attenuated (4) to opposite sympathetic hemodynamic drug effect with stimulation of the reninangiotensin system (5). The introduction of GTN patches, using the transdermal route of application and thus avoiding the hepatic denitration of transmucosal absorption is an attempt to halt the development of nitrate tolerance which causes diminished effect on systemic blood pressure and HR (6). The development of nitrate tolerance and also the withdrawal syndrome depends on the continuous exposure to nitrates, but 
cannot be prevented by intermittent transdermal application (7). The effect of transdermal nitroglycerin is effective in relation to the patch size, the drug release area, and is largely unaffected by skin characteristics or patch location (8). GTN patches with sustained release preparations, led to uniform plasma concentrations but caused "inter-individual variations" in healthy volunteers on hemodynamic parameters, independent of the GTN dose and plasma concentration (9). Otherwise, continuous high plasma concentrations induced contra regulatory mechanisms as the activation of the sympathetic system with vasoconstriction (5).

To understand the acute effect of transdermal GTN in healthy persons we analyzed the factors involved in drug absorption: the skin fold, body fat and skin temperature. Hemodynamic response to GTN was studied by the orthostatic reaction and related to individual variables as sex, subjective reactivity (as headache), smoking habit and family history of hypertension and diabetes in close relatives.

\section{METHODS}

A total of 63 healthy volunteers (27 men and 36 women) were treated once with transdermal patches containing $10 \mathrm{mg}$ of GTN. In a second turn, a total of 21 ( 9 men and 12 women) received a glycerin (GL) gauze patch as a placebo. Volunteers personal data are given as the mean \pm standard deviation, for age: $34.8 \pm 9.9$ years; for height: $161.4 \pm 9.8 \mathrm{~cm}$; for body weight: $65.3 \pm 11.9 \mathrm{~kg}$; and for lean body weight (LBW): $51.9 \pm 8.3 \mathrm{~kg}$.

The LBW was calculated according to the formula: $\mathrm{E}^{2} \times \mathrm{R},(\mathrm{E}=$ height in $\mathrm{cm}$; $\mathrm{R}$ for men $=0.002 ; \mathrm{R}$ for women $=0.0018)(10)$. The results allowed the calculation of the percentage of body fat content according to the formula:

[Body weight $(\mathrm{kg})$ - Lean body weight $(\mathrm{kg})$ ] / Body weight $(\mathrm{kg})$.

According to the calculated LBW and \% of fat content the 63 participants were classified in three subgroups:

\begin{tabular}{lccc}
\hline Subgroup & Number (n)) & LDW (kg) & Fat Content (\%) \\
\hline Lean & 31 & $42.3 \pm 2.7$ & $<12$ \\
Intermediate & 15 & $52.6 \pm 2.7$ & $12-17$ \\
Obese & 17 & $60.7 \pm 2.9$ & $>17$ \\
\hline
\end{tabular}

Skin fold was measured on both forearms innerside over a distance of $3 \mathrm{~cm}$; the mean value obtained was $9.6 \pm 3.6 \mathrm{~mm}$. Based on this parameter three subgroups were formed: Lean with $6.0 \pm 1.8 \mathrm{~mm}$, intermediate with $9.6 \pm 3.6 \mathrm{~mm}$ and obese with $12.2 \pm 4.4$ $\mathrm{mm}$.

In relation to smoking habits and hypertensive or diabetic close relatives, all the participants were classified as follows:

\begin{tabular}{lllc}
\hline Group & \multicolumn{2}{c}{$\begin{array}{c}\text { Smokers (more than } \\
15 \text { cigarettes/day) }\end{array}$} & Hypertension Diabetes \\
\hline GTN treated $(n=63)$ & 24 & 39 & 21 \\
GL treated $(n=21)$ & 12 & 11 & 8 \\
\hline
\end{tabular}

Transdermal patches of GTN (Nitradisc ${ }^{\mathrm{R}}$, Searle) of $10 \mathrm{mg}$ and a gauze containing $5 \mathrm{ml}$ of Glycerin (GL) were applied during 60 minutes on the left forearm innerside, over an area of $15.9 \mathrm{~cm}^{2}$ and $4.5 \mathrm{~cm}$ of diameter of GTN patch near the cubital region.

The following parameters were obtained: 1) The skin temperature was measured with an electrical thermometer in Celsius $\left({ }^{\circ} \mathrm{C}\right)$ on both forearms before and immediately after drug application for one hour. Further measurements were taken just after a UV-B irradiation for five minutes ( 65 minutes) and finally after 125 minutes from the beginning of the drug application The intensity of UV-B induced erythema on both arms was observed 24 hours later; 2) The hemodynamic parameters were studied in supine (10 minutes) and upright (2-3 minutes) position before and after the drug (GTN or GL) applications (60 and 125 minutes). The systolic (sAP) and diastolic (dAP) arterial blood pressures $(\mathrm{mm}-\mathrm{Hg})$ were registered by the auscultatory method and the mean arterial pressure (mAP) calculated by the equation:

$$
\mathrm{mAP}=[(\mathrm{sAP}-\mathrm{dAP}) / 3]+\mathrm{dAP}
$$

From the ECG (lead II), the HR (bpm) and the QTinterval (ms) were taken and corrected to QTc by Bazett formula (11).

The double product (DP) was calculated as DP = HR $\times$ SAP $\times 10^{-2}$.

Taken from a nomogram (Fig.1), one value was used to characterize the orthostatic ratio (OR) based on the difference between supine and upright positions for HR and mAP. A good hemodynamic adaptation on standing position reached values close to 100 . 


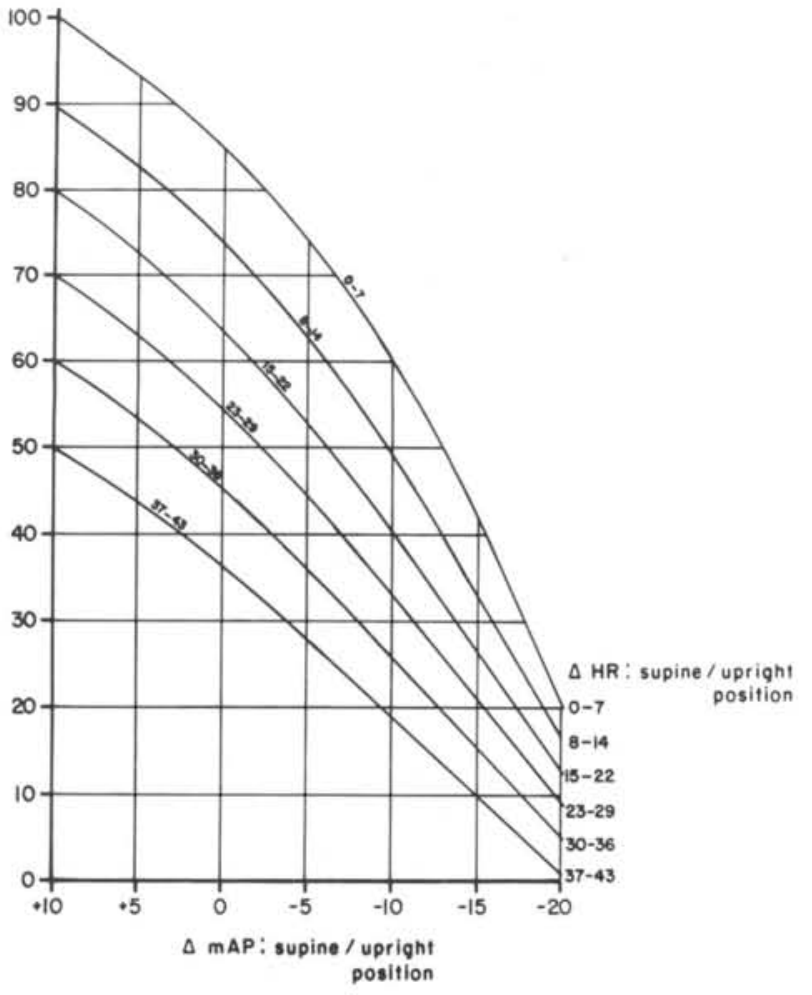

Figure 1-Nomogram used to obtain a single value characterizing the orthostatic reaction (OR). The OR is determined by the difference $\Delta$ in supine and upright position for the heart rate (HR) and the mean arterial pressure (mAP). These parameters are related to relative values (from 0 to 100 ) indicating individual performance.

\section{STATISTICAL METHODS}

For different variables a descriptive analysis was applied (BMDP-2D) and followed by BMDP-AM (12) to detect outliers. These outliers carried some pathological data and were eliminated from further studies. The evaluation continued by BMDP-2D for the GTN ( $n=63$ ) and $\mathrm{GL}(\mathrm{n}=21)$ groups resulting in homogeneous groups with normal limit parameters. The significance of the changes in the sense of "after" versus "before" of all parameters was analyzed by Student's t-test for paired measurements $(\mathrm{p}<0.05)(13)$.

The second phase included: the relationship of the group variables as skin fold, and body fat content to skin temperature on both forearms; and, the relationship of the group variables as gender, smoking habit, family hypertension, family diabetes and headache to the GTN effect on hemodynamic parameters (AP, HR, QTc) in supine and upright position, including the evaluation of the orthostatic reaction (OR).
For values obtained "before" and "after" the transdermal application of GTN in combination of the variables of the subgroups, the statistical model used was one of the type "split-plot" (14). Significance of 5\% is given for positive interaction "before" and "after" in all variables and their combinations.

For the skin temperature the repetition included eight levels due to significant interactions with intervals of confidence for multiple comparison by the Bonferroni Method (14).

\section{RESULTS}

\section{GTN effect on skin temperature}

Glycerin (GL) patches applied in 21 volunteers, on the left forearm did not alter the immediate $(60 \mathrm{~min}$.) and posterior (125 min.) skin temperature. The GTN patches in 63 participants, also applied during $60 \mathrm{~min}$. on the left forearm caused a significant skin temperature elevation on both arms (Fig. 2).

The UV-induced immediate thermoreaction (skin temperature after $65 \mathrm{~min}$.) and also the later photothermoreaction (Erythema after 24 hours) were attenuated after the previous application of GL and GTN patches on the left forearm.

Comparing the skin temperature on both forearms after 60 and $125 \mathrm{~min}$. we observed that the left sided effect was distinct and prolonged.

The left sided skin temperature of persons with a $13.2 \mathrm{~mm}$ skin fold $(\mathrm{n}=17)$ was high both after 60 and 125 min. in 3.2 and $3.6 \%$ when compared with values obtained "before". The right sided elevation of the skin temperature was smaller but also prolonged ( $2.6 \%$ after $125 \mathrm{~min}$.). After the application of the GTN patches, obese persons with more than $17 \%$ of fat content, showed a distinct elevation of the left sided skin temperature. This observation was clearly seen in men; otherwise, obese women had a greater and longer elevation of the right sided skin temperature than obese men. (Table I)

\section{GTN effect on hemodynamic-orthostatic reaction}

A comparative study of GL and GTN effects revealed that Glycerin (GL) did not alter the arterial pressure, the heart rate $(\mathrm{HR})$ and the QTc duration obtained from the ECG (Fig 3. and Table II). 
Table I

Skin Temperature $\left({ }^{\circ} \mathrm{C}\right)$

\begin{tabular}{|c|c|c|c|c|c|c|c|c|c|}
\hline & \multirow[b]{2}{*}{$\mathrm{n}$} & \multicolumn{3}{|c|}{ Left Forearm } & \multirow[b]{2}{*}{$125 \mathrm{~min}$} & \multicolumn{4}{|c|}{ Right Forearm } \\
\hline & & Before & After 60 & 65 & & Before & After 60 & 65 & $125 \mathrm{~min}$ \\
\hline $\begin{array}{l}\text { Glycerin } \\
\text { (GL) } \\
\Delta \% \\
\end{array}$ & 21 & $\begin{array}{l}32.3 \\
\pm 1.2\end{array}$ & $\begin{array}{l}32.5 \\
\pm 1.1 \\
+0.4 \\
\end{array}$ & $\begin{array}{l}35.4^{\star} \\
\pm 1.1 \\
+9.4^{\star}\end{array}$ & $\begin{array}{l}32.3 \\
\pm 1.2 \\
\pm 0.0 \\
\end{array}$ & $\begin{array}{l}32.1 \\
\pm 1.2\end{array}$ & $\begin{array}{l}32.3 \\
\pm 1.0 \\
+0.5 \\
\end{array}$ & $\begin{array}{c}35.8^{\star} \\
\pm 0.9 \\
+11.4^{\star}\end{array}$ & $\begin{array}{l}32.1 \\
\pm 1.1 \\
+0.0\end{array}$ \\
\hline $\begin{array}{l}\text { Nitroglycerin } \\
\text { (GTN) } \\
\Delta \% \\
\end{array}$ & 63 & $\begin{array}{l}31.1 \\
\pm 1.1\end{array}$ & $\begin{array}{l}31.9^{\star} \\
\pm 1.0 \\
+2.3^{\star}\end{array}$ & $\begin{array}{l}34.2^{\star} \\
\pm 1.3 \\
+9.7^{\star}\end{array}$ & $\begin{array}{r}31.7 \\
\pm 1.2 \\
+1.8^{*}\end{array}$ & $\begin{array}{l}31.1 \\
\pm 1.1\end{array}$ & $\begin{array}{l}31.4^{\star} \\
\pm 1.2 \\
+1.1^{\star}\end{array}$ & $\begin{array}{c}34.6^{*} \\
\pm 1.6 \\
+11.4^{*}\end{array}$ & $\begin{array}{l}31.4 \\
\pm 1.2 \\
+0.9^{\star}\end{array}$ \\
\hline $\begin{array}{l}\text { Nitroglycerin } \\
\text { Skin Fold } \Delta \% \\
6.0 \pm 1.8 \mathrm{~mm} \\
9.6 \pm 3.6 \\
13.2+4.4 \\
\end{array}$ & $\begin{array}{l}31 \\
15 \\
17 \\
\end{array}$ & & $\begin{array}{l}+1.7 \\
+2.4 \\
+3.2 \\
\end{array}$ & $\begin{array}{r}+7.5 \\
+11.7 \\
+11.1 \\
\end{array}$ & $\begin{array}{l}+1.3 \\
+0.8 \\
+3.6\end{array}$ & & $\begin{array}{l}+0.9 \\
+1.0 \\
+1.5 \\
\end{array}$ & $\begin{array}{c}+8.7 \\
+14.2 \\
+12.4 \\
\end{array}$ & $\begin{array}{l}+0.2 \\
-0.4 \\
+2.6 \\
\end{array}$ \\
\hline $\begin{array}{l}\text { Body Fat and } \\
\text { Gender } \Delta \% \\
<12 \%\end{array}$ & $\begin{array}{c}18 \\
8 \\
10\end{array}$ & & $\begin{array}{l}+0.9 \\
+2.1 \\
+2.5 \\
\end{array}$ & $\begin{array}{c}+4.8 \\
+6.8 \\
+11.4 \\
\end{array}$ & $\begin{array}{r}-3.2 \\
+1.3 \\
+2.4 \\
\end{array}$ & & $\begin{array}{l}+0.8 \\
+2.1 \\
+2.6 \\
\end{array}$ & $\begin{array}{r}+7.8 \\
+9.8 \\
+10.4 \\
\end{array}$ & $\begin{array}{l}-1.3 \\
+0.8 \\
+1.9 \\
\end{array}$ \\
\hline $\begin{array}{ll}<12 \% & \sigma^{\pi} \\
12-17 \% & \sigma^{\pi} \\
>17 \% & \sigma^{\pi} \\
\end{array}$ & $\begin{array}{c}13 \\
6 \\
8 \\
\end{array}$ & & $\begin{array}{l}+1.4 \\
+2.4 \\
+3.4\end{array}$ & $\begin{array}{r}+7.7 \\
+8.7 \\
+10.4 \\
\end{array}$ & $\begin{array}{l}+2.3 \\
+1.6 \\
+1.9 \\
\end{array}$ & & $\begin{array}{l}+1.0 \\
+1.5 \\
+1.6\end{array}$ & $\begin{array}{r}+8.9 \\
+10.7 \\
+10.1\end{array}$ & $\begin{array}{l}+2.1 \\
+1.0 \\
-0.1\end{array}$ \\
\hline
\end{tabular}

$\left(^{*}\right)=$ Significance $p<0.05$

In all volunteers $(n=63)$ a significant GTN effect appeared in the supine body position 60 minutes after the patch application with only a small decrease in the arterial pressure $(-1.8 \%)$; in the upright position, GTN patches caused a significant decrease of the systolic $(-3.1 \%)$ and diastolic $(-3.2 \%)$ pressures and an increase in heart rate $(+7.4 \%)$, when compared to "before". Consequently the orthostatic reaction (OR) was reduced in $8 \%$. The QTc duration from the ECG was prolonged from $0.4060 \pm 0.03$ $\mathrm{ms}$ "before" to $0.4260 \pm 0.04 \mathrm{~ms}(\mathrm{p}<0.05)$ "after" the GTN application, indicating a significant prolongation of $4.9 \%$ (Table III),

The prolongation of the QTc interval was also found in supine position, but only in men $(n=27)$, regardless of complains of GTN induced headache.

Different groups presented significant altered orthostatic reaction (OR) in a range of -6.6 to $-14.1 \%$ related to the situation "before". The OR was negative $(-8.0 \%)$ in the group with a positive family history of hypertension and diabetes and also in male smokers. In these groups the GTN patches provoked in the supine position a significant decrease in arterial pressure (sAP and dAP). In the upright position, only in the group with hypertensives in the family $(n=39)$ and male smokers $(n=15)$ we observed a clear hypotensive reaction. In this body position a tachycardial reaction but without hypotension was seen in the group with diabetes in close relatives.

Men $(n=7)$ who presented headache after the the application of GTN patches during $60 \mathrm{~min}$. responded differently: in the supine position, with a increased systolic pressure $(+23 \%)$, with a decreased diastolic pressure $(-10.4 \%)$ and a prolonged QTc interval $(+5.4 \%)$; in upright position, only a decreased diastolic pressure ($10.4 \%)$ and a increased heart rate (HR) $(+17.7 \%)$ was observed. 


\section{DISCUSSION}

\section{GTN effect on skin temperature}

Only the GTN patches and not the GL (placebo) patches caused a significant elevation of the skin temperature on both arms. This observation suggests a local (left sided) and a systemic (right sided) vasodilating effect. The local as well as the initial $(60 \mathrm{~min}$.) and later (125 min.) GTN effect on skin temperature was accentuated when compared with the systemic effect.

Earlier studies had also shown that the sublingual nitroglycerin in normal subjects $(n=11)$ increased the forearm blood flow, lowered the forearm vascular resistance due to a reduced venous tone. The mean arterial pressure (mAP) declined slightly (15).

An UV induced thermoreaction was used to differentiate alterations of the skin temperature due to capillary or vascular dilation. The UV induced erythema was evident on the right arm and pale or not visible on the left arm, indicating an inhibition of the local UV effect after previously applied GL and GTN patches. This observation may be related to a known inhibition of heparin activity due to glyceryltrinitrate (GTN) $(16,17)$. An interaction of GL and GTN with stimulants which releases heparin and also histamin may be considered. GTN as an inhibitor of heparin activity may also decrease the UV induced histaminergic reactivity in the skin.

Local factors may facilitate the drug absorption and influence the GTN effect. In obese men and women, the local and systemic drug effect on skin temperature is higher. In persons with a greater skinfold and a greater body fat content we observed a greater local, and a moderate systemic elevation of the skin temperature, when compared to lean persons. Approximately two hours (125 min.) after the application of the GL patches and UV application the skin temperature returned to the values obtained "before". After GTN patches and UV irradiation the skin temperature reached this level only in lean women and obese men; the GTN effect in these groups is abbreviated.

The transdermal absorption of GTN, a lipophylic compound, seems to be higher in obese persons. In obese women there may be a redistribution of the drug, as known to occur with barbiturates, which explains the prolonged effect on skin temperature not seen in lean women. A short drug effect was observed in obese men; a rapid breakdown and inactivation of the drug, or more likely, a counteracting vasoconstrictor GTN effect may be responsible for this effect.

Table II

Nitroglycerin - Hemodynamic parameters of groups

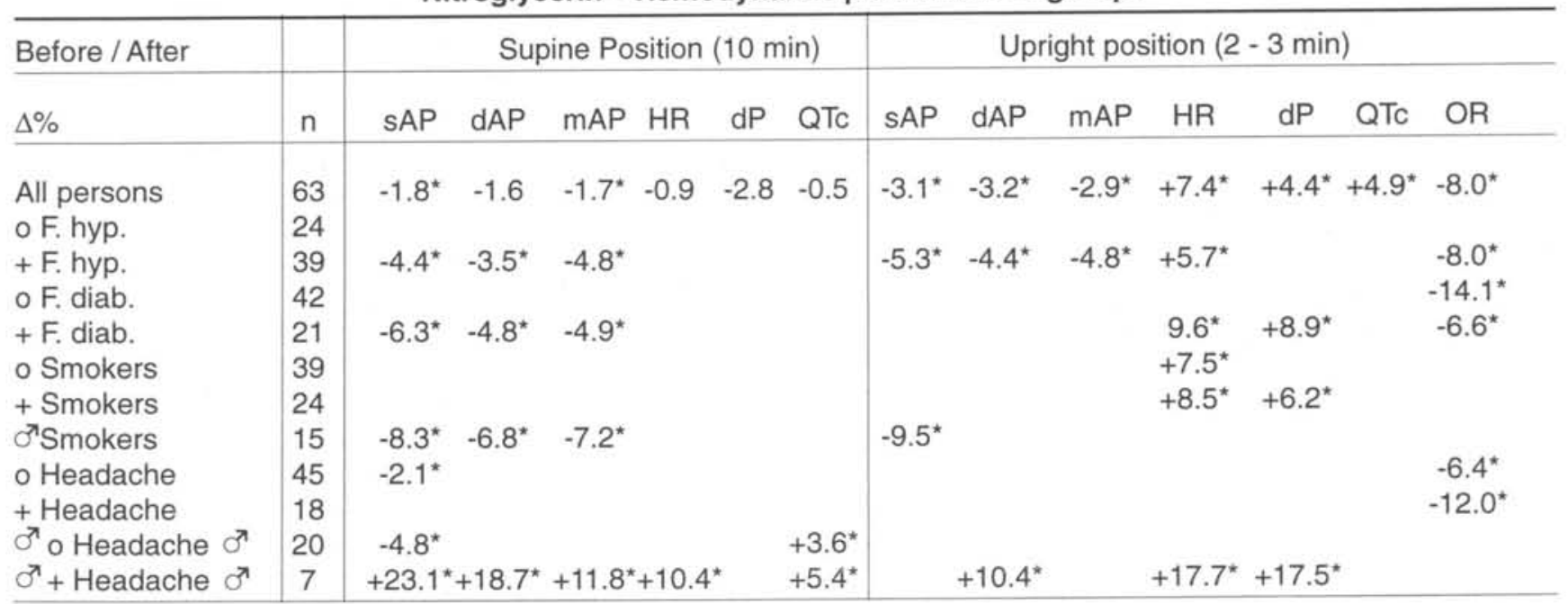

$s A P, d A P, m A P=$ systolic, diastolic, mean arterial blood pressure $(\mathrm{mmHg}) ; H R=$ heart rate $(\mathrm{bpm}) ; D P=$ double product; $Q T C=$ corrected systolic interval; $O R=$ orthostatic reaction; $D \%=$ percent difference related to before values; $\left({ }^{*}\right)=$ significance $p<0.05$. 


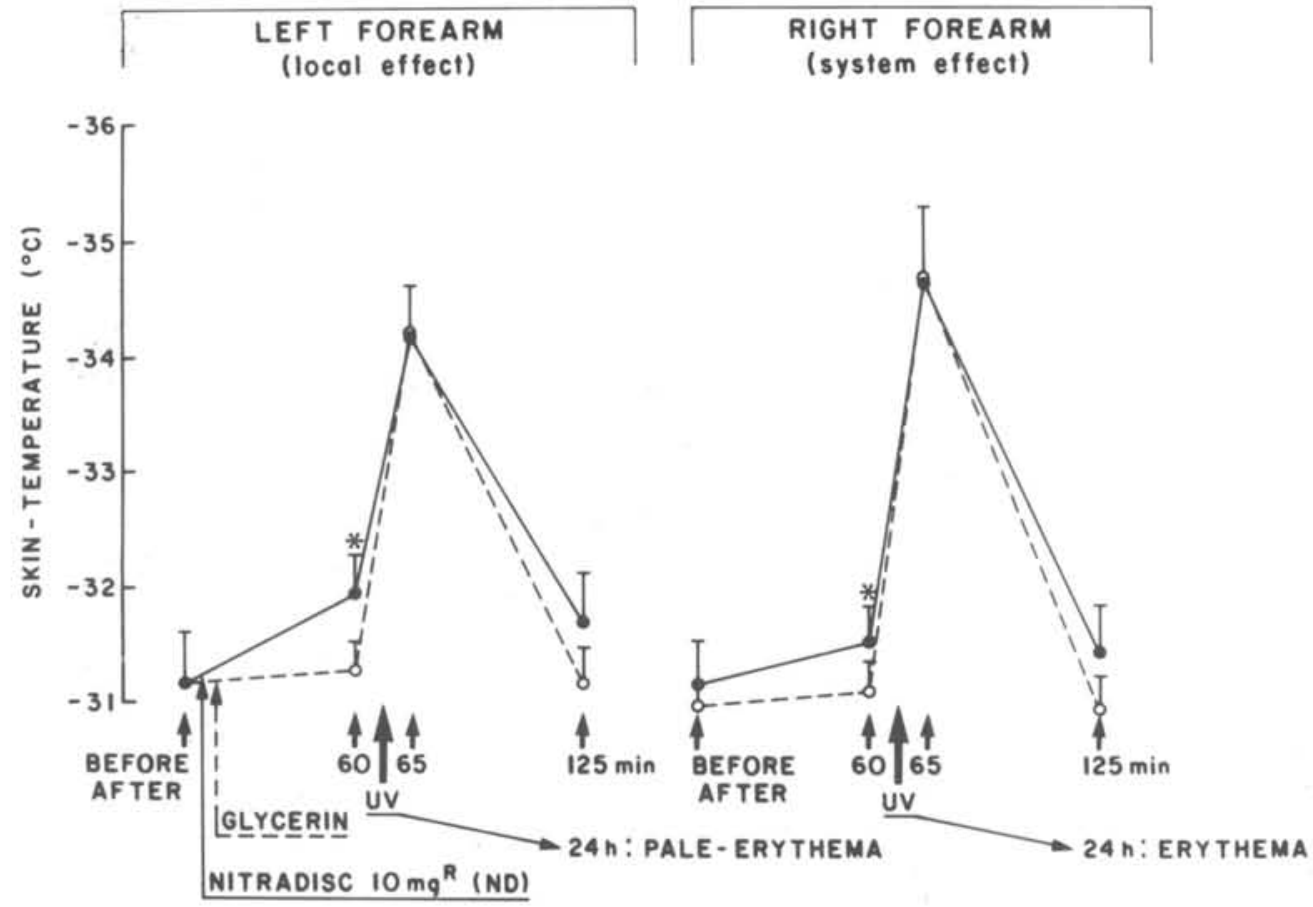

Figure 2 - Skin temperature $\left({ }^{\circ} \mathrm{C}\right)$ measured on both forearms, before and 60,65 and 125 minutes after left sided glycerin (GL) or nitroglycerin (GTN) application.

\section{GTN effect on hemodynamic-orthostatic reaction}

Our results obtained from 63 healthy middle aged persons confirm known acute GTN effects $(18,9)$. In the standing position, the decrease of the arterial blood pressure with increased heart rate (HR) resulted in a reduced performance of the orthostatic reaction (OR) not observed after application of GL patches. A negative orthostatic reaction $(\mathrm{OR})$ indicates a moderate GTN effect with hypotension and tachycardia. The same result $(-8 \%)$, as the mean value from all volunteers, was also observed in the group with a positive family history of hypertension, where in both body positions the arterial blood pressure was decreased but only in upright position the heart rate increased.

GTN increases the peripherical blood flow reducing the venous tone (15); with low GTN concentrations the venous dilatation predominates over that of arterioles (19).

A GTN induces postural hypotension due to "venous pooling", enhances the activity of baroreceptors, leading to a secondary "reflex" change of the heart rate (HR) by a sympathetic discharge. Simultaneously an adrenergic stimulation of the left stellate ganglion, responsible for the "long QT syndrome" (20) may explain the QTc prolongation after GTN, as reported earlier (21). Supposing the stimulation of the left stellate ganglion due to GTN is correct and responsible for the QTc prolongation then the men studied, responded to GTN with an augmented sympathetic discharge.

In healthy persons, a previous individual physiological condition may explain the differences in the drug effect.

In the group with a positive history of diabetes in the family and also in male smokers, GTN patches provoked in the supine position, a clear hypotensive reaction and in upright position, a tachycardial response, without hypotension.

Individual and adverse responses to one small dose of transdermal applied GTN may be due to interactions of endogenous versus exogenous vasodilators, nitric oxide (NO) $(22,23)$, endothelium derived relaxing factor $(\mathrm{EDRF}=\mathrm{NO})$ versus contracting factors $(\mathrm{EDCF})(24)$ and endogenous vasoactive substances (25) and also the reninangiotensin system $(5,26)$.

Nitric oxide (NO) as an exogenous vasodilator, is derived from GTN, named nitroglycerin. GTN is metabolized in the presence of the sulfidryl group (SH) to nitric oxide (NO) in the vascular smooth muscle cells. The smooth muscle relaxing factor is cyclic guanosine $3^{\prime}{ }^{\prime}$ monophosphate (cGMP) produced by the activation of the SH containing-enzyme, the guanylate-cyclase (27). The cGMP is the mediator for the exogenous NO and also the 


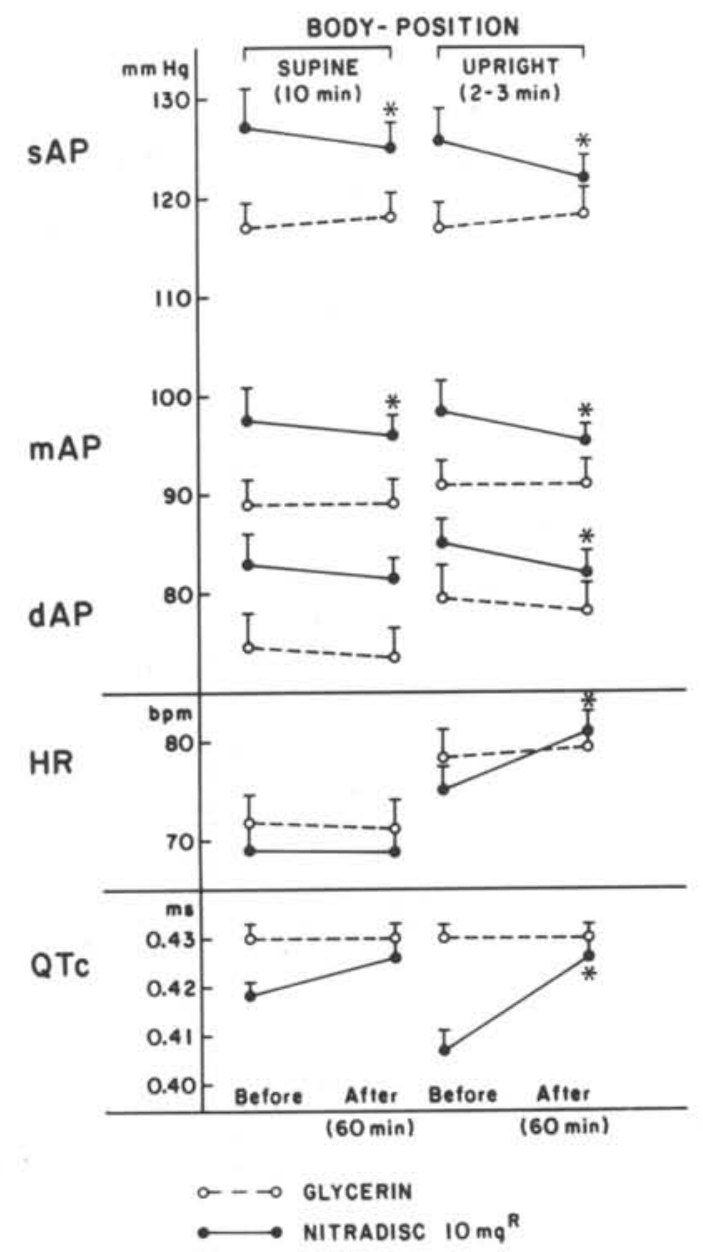

Figure 3-Hemodynamic parameters, systolic, diastolic and mean arterial blood pressure (sAP; dAP; mAP) in $\mathrm{mm}-\mathrm{Hg}$, heart rate (HR) in bpm, and QTc interval in ms are given as mean values with their standard deviation, before and 60 minutes after a transdermal nitroglycerin (GTN) or glycerin (GL) application.

endogenous $\mathrm{EDRF}=\mathrm{NO}$ induced smooth muscle relaxation (22).

The endothelium derived releasing $\operatorname{EDRF}(=\mathrm{NO})$ interacts with the modulation of the vascular reactivity by other endogenous vasoactive substances (25). It has been experimentally proved that the endothelial cells have the capacity to inactivate noradrenalin, serotonin and bradykinin, whereas prostaglandin formation is enhanced (26). Otherwise nitroglycerin, the exogenous NO induces the production of prostacyclin by human endothelial cells (27).
The activation of cGMP by nitric oxide is competitive. The endothelium derived NO is an inhibitor of the GTN derived NO. A reduced EDRF release like under pathological conditions, failes to inhibit the exogenous NO activity on guanylate cyclase, thus potenciating the GTN effect. In healthy young people, due to a NO competition, the GTN derived NO activity may be reduced (25).

The interaction of the vasodilating GTN derived "exogenous" nitric oxide (NO) and the endothelium derived "endogenous" factor (EDRF=NO) is important but extrarenal renin release controlled by dietary potassium must be considered (28).

The renin-angiotensin system is involved in hemodynamic regulation as can be seen in the interaction of GTN and Captopril (29). Captopril, a compound containing a sulphydryl group inhibits the angiotensin converting enzyme (ACE) and also the breakdown of bradykinin. Captopril reverts nitrate tolerance probably due to an activation of the SH-containing guanylate cyclase (30).

Low as well as a high renin activity mediated by angiotensin, modifies the adrenal cortex sensitivity leading to hyper- or hypotension (31). With a supposed reduced adrenal cortex sensitivity due to high renin activity, the GTN induced hypotension is accentuated as seen in male smokers and persons with hypertensive and diabetic close relatives.

We observed that the transdermal GTN provoked a mainly postural hypotension in $89 \%$ and a hypertensive reaction in $11 \%$ of all participants. In the same volunteers who participated in an earlier clinical study (32) and also in this study we observed low potassium $\left(\mathrm{K}^{+}\right)$level in plasma as well as an orthostatic hypodiastolic hypotension (33). The adverse paradoxal hypertensive GTN effect was only seen in men and was quite similar to the effect described by Murrel in 1879, after oral nitroglycerin doses (1). The men who responded to GTN with a headache had a tendency to an evident activity of vasoactive substances (serotonin, histamin, bradikinin and others) associated with a sympathetic reaction compatible with a "low renin hypertension". The greater group with a GTN induced postural hypotension may have an underlying "high renin" activity. Dietary potassium has also an influence over the renin release (28) and may be one of the determining factors for individual reactions to GTN (fig. 4). Counter regulatory neurohumoral factors and mechanisms such as enhanced catecholamin activity and stimulation of the renin angiotensin system may also be involved in the variability of nitrate tolerance (34). 


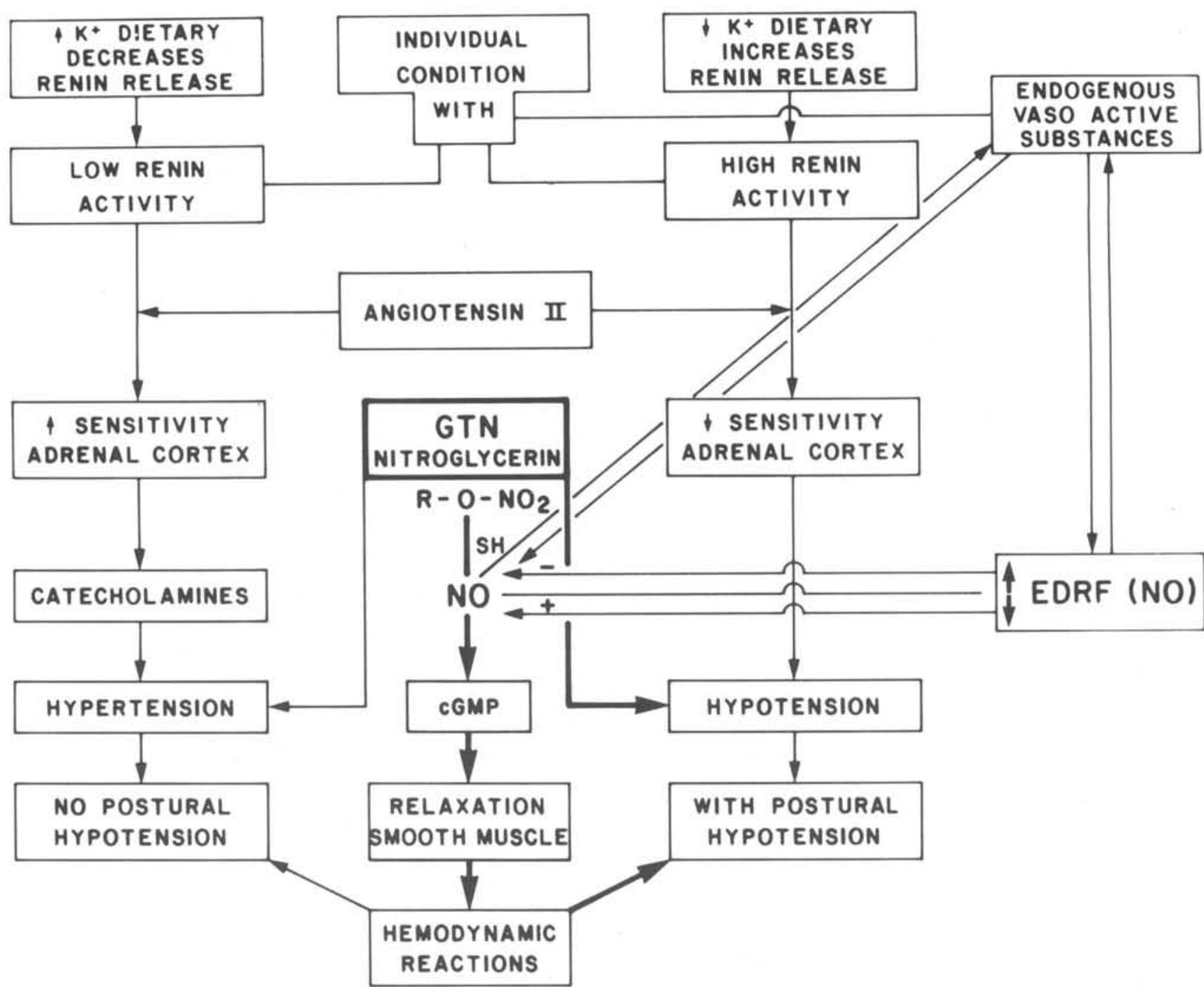

Figure 4-Individual conditions such as dietary potassium $\left(\mathrm{K}^{+}\right)$and basically different activity of endogenous vasoactive substances may be responsible for a modified glyceryltrinitrate (GTN) drug effect. Transdermal GTN provoked a hypertensive reaction in $11 \%$ and a mainly postural hypotension in $89 \%$ of the investigated persons $(n=63)$.

\section{CONCLUSIONS}

The individual reactions to transdermal GTN revealed: 1) that one hour of application produces an effect on skin temperature mainly in obese women; 2 ) that the local and systemic GTN effect depends on arteriolar and not on (UV induced) capillary dilation; 3 ) that in healthy persons $(n=63)$ transdermal GTN caused a moderate orthostatic reaction with a slightly decreased arterial pressure, increased heart rate and QTc prolongation; 4) that GTN in the supine position provoked individual reactions; in men $(\mathrm{n}=7)$ an adverse sympathetic reaction was observed associated with headache in supine and upright position.

\section{AKNOWLEDGMENTS}

To M.T. Cavalcante, for technical assistance, to D.A. Botter and C. Qu. Aubin for the statistical analysis and to J.J. Leite for the revision of the paper. 


\section{Resumo}

Materiais e Métodos: Em 63 pessoas, antes e após aplicação tópica de discos com nitroglicerinaß ou glicerina como placebo, foram avaliadas: a temperatura cutânea em ambos os antebraços e as relaçōes hemodinâmicas em posição supin e ortostática. Resultados: As respostas foram as seguintes: 1. Uma hora após aplicação unilateral (no antebraço esquerdo) houve aumento da temperatura cutânea também no antebraço direito, indicando efeito sistêmico; esse efeito era mais acentuado e prolongado em mulheres obesas. 2. A fototermo-reaçâo (eritema) induzida com luz ultravioleta (UV) foi menor no antebraço esquerdo, sugerindo que a nitroglicerina age mais sobre arteríolas do que sobre capilares do sistema vascular. 3 . A aplicaçāo transdẻrmica de nitroglicerina causou uma moderada reação ortostática com diminuição da pressão arterial e aumento da freqüência cardiaca. A duraçāo do Qtc no ECG era prolongada. 4. Foram observadas as seguintes reaçōes individuais em posição supina: em 7 homens houve uma reação adversa com aumento da pressão média em $+12 \%$ e aumento da freqūência cardiaca em $+10 \%$; a mesma reaçäo (simpática?) foi descrito por Murell em 1879 , após nitroglicerina v.o. Em homens fumantes $e$ aqueles com hipetensāo e diabetes em membros próximos da familia, o efeito hipotensor após nitroglicerina transdérmica era acentuado em posiçāo supina.

\section{REFERENCES}

1. PARRAT, J.R. - Nitroglycerin - the first one hundred years: new facts about an old drug (review). J. Pharm. Pharmacol. 31:801-809, 1979.

2. KATZUNG, B.G. \& CHATTERJEE K. - Vasodilators and treatment of angina pectoris. In Bertram G. Katzung (Editor): Basic and Clinical Pharmacology. Ed. 4. Rio de Janeiro, Prentice - Hall International, p. 149, 1989.

3. KALTENBACH, M \& SCHNEIDER, W. - Fortbestehen der antianginoesen Wirksamkeit unter chronischer Nitrattherapie trotz Aufhebung haemodynamischer Teileffekte. Dtsch. Med. Wschr. 111:383-386, 1986.

4. FLAHERTY, J.T. - Clinical relevance of Nitrate hemodynamic attenuation. Am. Heart J. 112(1): 216-220, 1986.

5. BASSENGE, E.D. \& STEWART, D.J. - Effects of nitrates in various vascular sections and regions. Z. Kardiol. 75(3): 17, 1986.

6. PARKER, J.O. - Efficacy of nitroglycerin patches: fact or fancy? Ann. Int. Med. 102(4):548-549, 1985.

7. ODENTHAL, H.J., WIECHMANN, H.W., JOSEPHS, W. \& LENGA, P. - Transdermale Nitroglycerinsysteme mit kontinuierlicher und diskontinuierlicher Substanzfreisetzung. Vergleich anti-ischaemischer und haemodynamischer akut und Langzeit-Wirkung. Dtsch. Med. Wschr. 116:241-247, 1991.

8. CARASH, B. \& SCHEIDT, S.S. - The controversy over transdermal nitroglycerin: an update. Am. Heart J. 112(1):207-215, 1985.
9. MUELLER, P. IMHOF, P.R., BURKART, F., CHU, L.C. \& GÉRADIN, A. - Human pharmacological studies of a new transdermal system containing nitroglycerin. Eur. J. Clin. Pharmacol. 22: 473-480, 1982.

10. BEHNKE, A.R. - The relation of lean body weight to metabolism and some consequent systematizations. Ann. N.Y. Acad. Sci. 56:1095-1142, 1953.

11. BAZETT, H.C. - An analysis of the time relations of electrocardiograms. Heart 7:353-370, 1920.

12. DIXON, W.J. - BMDP-statistical software. Berkeley University of California Press, 1981.

13. BUSSAB, W.O. \& MORETTI, P.A. - Estatística Básica. 3a. ed. São Paulo, Atual Editora, 1986.

14. WINER, B.J. - Statistical principles in experimental design. Ed. 2. New York, McGraw-Hill, p. 907, 1971.

15. MASON, D.T. \& BRAUNWALD, E. - The effects of nitroglycerin in amylnitrite on arteriolar and venous tone in the human forearm. Circulation 32:755-766, 1965.

16. PIZZULLI, L., NITSCH, J. \& LUEDERITZ, B. - Hemmung der Heparin-Wirkung durch Glyceroltrinitrat. Dtsch. Med. Wschr. 113:1837-1840, 1988.

17. PIZZULLI, L. , KOEHLER, U., NITSCH, J. \& LUEDERITZ, B. - Arzneimittelinteraktion zwischen Glycerol-trinitrat und Heparin. Z. Kardiol. (77 suppl.) 1:8386, 1988.

18. COHN, P.F. \& GORLIN, R. Physiologic and clinical actions of nitroglycerin. Med. Clin. North. Am. 58:407-412, 1974.

19. NEEDLEMAN, P., CORR, P.B. \& JOHNSON JR., E.M. Drugs used for treatment of angina: organic nitrates. In Goodman and Gilman (Editors). The pharmacological Basis of Therapeutics. Ed. 7. New York, Macmillan Publishing, 1985, p. 806-816. 
20. CRAMPTON R. - Prominence of the left stellate ganglion in the long QT syndrome. Circulation, 59:769-778, 1979.

21. LEPESCHKIN E. - Vasodilatatory drugs: Nitroglycerine. In Lepeschkin E. (Editor). Modern electrocardiography. Vol. 1. Baltimore, The Williams and Wilkins, 1951, p. $302-$ 303.

22. MONCADA, S. , PALMA, R.M.J. \& HIGGS E.A. - The discovery of nitric oxide as the endogenous nitrovasodilator. Hypertension 12(4):365-372, 1988.

23. BUSSMANN, W.D. - Nitratpflaster: WirkungsdauerWirkungsverlust. Uberlegungen zum Wirkungsmechanismus von Nitraten. Dtsch. Med. Wschr. 114:2023-2026, 1989.

24. LUESCHER, T.F.- Endotheliale Relaxation und Kontraktion. Dtsch. Med. Wschr. 116:747-754, 1991.

25. FOERSTERMAN, U. - EDRF (endothelium derived relaxing factor) der koerpereigene Nitrovasodilatador. Dtsch. Med. Wschr. 113:1215-1217, 1988.

26. CARVALHO, M.H.C., SCIVOLETTO R. , FORTES, Z.B. \& NIGRO, D. - The role of endothelium in vascular reactivity. Brazilian J. Med. Biol. Res. 22:533:545, 1989.

27. LEVIN, R.D., WEKSLER, B.B. \& JAFFÉ E.A. Nitroglycerin induces production of prostacyclin by human endothelial cells. Clin. Res. 28:417A, 1980.
28. WILLIAMS, G.H. \& DLUHY R.G. - Diseases of the adrenal cortex. In Wilson, J.D. et al. (Editors). Harrison's Principles of internal medicine. 12 ed., New York, São Paulo, McGraw Hill, 1991, p. 1716.

29. LAWSON, D.L., NICHOLS, W.W., MEHTA, P. \& MEHTA, J.L. - Captopril induced versal of nitroglycerin tolerance: role of sulphydryl groups versus ACE-inhibitory activity. J. Cardiovascular Pharmacology 17:411-418, 1991.

30. GOLDBERG, N.D. - Guanylatocyclase contem sulphydryl groups. Ann. Rev. Biochem. 46:823-896, 1977.

31. WILLIAMS, G.H. - Hypertensive vascular disease. In Wilson, J.D. et al. (Editors). Harrison's Principles of internal medicine. 12 ed., New York, São Paulo, McGraw Hill, 1991, p. 1005.

32. BOECKH HAEBISCH, E.M.A. - Pharmacological Trial of a concentrated crude extract of Stevia rebaudiana (Bert) Bertoni in healthy volunteers. Arq. Biol. Tecnol. 35(2):299314, 1992.

33. SCHMIDT, R.F. \& THEWS, G. - Human Physiology. Tests of orthostatic response. 20 Ed.. Berlin, Heidelberg, New York, Springer-Verlag, 1983, p. 442.

34. REYNEN, K. - Nitrate. Dtsch Med. Wschr. 118:1532-1539, 1993. 